\title{
GCGR Gene Mutation
}

National Cancer Institute

\section{Source}

National Cancer Institute. GCGR Gene Mutation. NCI Thesaurus. Code C157455.

A change in the nucleotide sequence of the GCGR gene. 